\title{
INFLUENCE OF ORGANIC AND BIO CONDITIONERS ON CALCAREOUS SOIL PROPERTIES AND YIELD OF BROAD BEAN PLANT
}

\author{
Nahed A. M. E. Aiad \\ Soil, Water and Environ. Res. Inst., Agric. Res. Center (ARC), Giza, Egypt \\ Received: Oct. 14,2017 \\ Accepted: Oct. $\quad 30,2017$
}

\begin{abstract}
A field experiment was conducted on calcareous soil at El- Nubaria (private farm at the 10,000 Fed Village), El- Behera Governorate for two successive winter seasons (2015- 2016) and (2016- 2017). Broad bean plant ( Vicia faba. Nubaria 1) was used as a tested plant to study the efficiency of some conditioners, compost (town refuse), potassium humate as organic and Rhizobium leguminosarum bv. Viceae strain ICARDA 441 as bio fertilizers on some calcareous soil properties and yield of broad bean. The treatments were: AThe cultivation methods (row and strew). B-The conditioners: organic (compost 10 ton fed ${ }^{-1}$ and potassium humate $15 \mathrm{~L} \mathrm{fed}^{-1}$ ) and bio (Rhizobium leguminosarum bv. viceae strain ICARDA 441). Results indicated that, $\mathrm{EC}, \mathrm{pH}$ and $\mathrm{CaCO}_{3} \%$ of the studied soil were decreased, where OM was increased as a result of using both organic and bio conditioners compared to the control treatment. An improvement in soil physical properties as affected by soil conditioners was observed. Wherever a slight decreased soil bulk density (BD), an increase in total porosity (TP) and soil aggregation as dry and wet stable aggregates at using organic conditioners than biofertilizer were occurred. As well as soil hydraulic conductivity $(\mathrm{HC})$ and moisture content at both field capacity (FC) and available water (AW) were increased compared to the control. Town refuse compost application achieved the highest biological, grain yield and 100 grains weight of broad bean plant followed by potassium humate treatment. Generally, the different soil properties and crop yield of broad bean plant grown on calcareous soil was more affected by the row cultivation method, town refuse compost and potassium humate, than bio fertilizer addition compared to the control.
\end{abstract}

Key words: compost, potassium humate, biofertilizer, calcareous soil and broad bean.

\section{INTRODUCTION}

Broad bean (Vicia faba L.) is one of the most important legumes in Egypt. It is intensively used by both human and animals in many countries worldwide. It is considered as a cheap diet containing high protein and energy. Therefore, efforts to improve the quality and quantity of the vegetable crop are important in Egypt.

Calcareous soils are typical ones in Egypt. The main problems of these soils are related to one or more of the following: high salinity, high $\mathrm{pH}$, lack of adequate texture and structure, very poor in organic matter or biological activities, and macro and micronutrients availability. A great attention has been directed towards the use of organic fertilizers to reduce plant and soil contaminations with mineral fertilizers, improve the fertility of soil and reduce nutrient losses. In addition, the organic fertilizers were considered good sources of plant nutrient supply and good soil conditioners El-Maaz et al. (2010). Addition of organic matter, can improve all soil properties; such as water holding capacity, soil aggregation and aggregation stability, El-Maaz et al. (2014) concluded that compost application decreased soil $\mathrm{pH}$ and EC but increased soil organic matter, fertility, and increase cation exchange capacity. Also organic fertilizers were used to decrease soil $\mathrm{pH}$ and increase the availability of major and minor nutrients. Abd El-Moez et al. (2002) found that, 
application of composted materials to the saline calcareous soil decreased both EC and $\mathrm{pH}$ values. As the universe is going now the way of clean agriculture and minimizing pollution effects, organic and biofertilizers become the best products to improve soil properties and productivity. They are considered as the most important factor in reducing the application of the inorganic fertilizers; consequently, reduce the adverse environmental impact of chemicals (Marschner, 1995). It is one of the management goals to increase and maintain soil quality with a high biological activity. Today application of bio fertilizer to limit the use of mineral fertilizers and supports an effective tool for new lands development under less polluted environments decreasing agricultural costs, maximizing crop yield due to providing them with an available nutritive elements and growth promoting substances (Metin et al., 2010).

Bio-fertilizers were successfully used to minimize the dependence on chemical fertilizers. Biofertilizers are environment friendly, less costly, and therefore lead to sustainable crop production (Kassem and Hassouna, 2004; Choudhury et al., 2014 and Naher et al., 2016). Biofertilizer increases soil fertility and crop yield, the use of bio-fertilizers has currently attained a special significance in crop production to address the sustainability issues (Singh, 2014). Also, bio-fertilizers are known to play an important role in increasing availability of nitrogen and phosphorus beside improving biological fixation of atmospheric nitrogen and produce hormones and anti metabolites (Bhat et al., 2013).

The objective of this study aims to improve soil physical and chemical properties, plant growth and yield of broad bean plants grown on calcareous soil by application of compost, potassium humate and bio fertilizer (Rhizobium leguminosarum bv. Viceae strain ICARDA 441) under two cultivation methods (row and strew) .

\section{MATERIALS AND METHODS:}

A two field experiment was conducted on calcareous soil of a private farm at the Ten Thousand Fed Village, El- Nubaria, ElBehera Governorate to study the efficiency of some conditioners, compost (town refuse), potassium humate as (organic) and Rhizobium leguminosarum bv. Viceae strain ICARDA 441 as bio fertilizers with two cultivation methods (row and strew) on some soil properties and productivity of broad bean plant during two successive winter seasons of (2015 -2016 and 20162017).

The following treatments were applied:

A- The cultivation methods (row and strew).

B- The conditioners: organic (compost 10 ton fed $^{-1}$ and potassium humate $15 \mathrm{~L}$ fed $^{-1}$ ) and bio (Rhizobium leguminosarum bv. viceae strain ICARDA 441)

The experimental design was a split plot design with three replicates. The plot aria was $3.5 \times 3.0 \mathrm{~m}^{2}$. The main plots were cultivation methods (row and strew), sub plots were compost, potassium humate, bio fertilizers and control. Compost was thoroughly incorporated with surface soil layer $25 \mathrm{~cm}$ at two weeks before cultivation. Potassium humate were added as soil application at three times (after vegetative stage, beginning of flowering stage and beginning of fruiting stage). Bio fertilizers were added as seed inoculation just before sowing (seed coating method)

Broad bean (Vicia faba, Nubaria 1) was cultivated on first half of November then harvested in May. Mineral fertilizers were added as $100 \%$ of recommended doses from $\mathrm{N}, \mathrm{P}$ and $\mathrm{K}$. Nitrogen added as an activator doses at sowing in the form of ammonium sulfate $(20 \% \mathrm{~N})$ at the rate 20 $\mathrm{kg}$ fed $^{-1}$. Potassium added at the form potassium sulfate $\left(48 \% \mathrm{~K}_{2} \mathrm{O}\right)$ at the rate 50 $\mathrm{kg} \mathrm{fed}^{-1}$ in two equal doses at sowing and 30 days from planting. Superphosphate $(15.5 \%$ $\mathrm{P}_{2} \mathrm{O}_{5}$ ) at the rate $150 \mathrm{~kg}$ fed $^{-1}$ added basically before planting during soil preparation. 
Disturbed and undisturbed surface soil samples $(0-30 \mathrm{~cm})$ were taken from the experimental field before planting, air dried and prepared for analyzing. Some soil physical and chemical characteristics of the studied soil were determined according to Page et al. (1982) and the obtained data were presented in Table (1). Some characteristics of compost and potassium humate were determined according to Page et al. (1982) and the obtained data were recorded in Table $(2-a, b)$. Soil samples were also collected from the surface layers (0-30) from each plot separately before harvest. The soil samples were air- dried ground, sieved and analyzed for some chemical characteristics, i.e., soil $\mathrm{pH}$, organic matter (OM) and total calcium carbonate $\mathrm{CaCO}_{3} \%$ according to the methods described by Page et al. (1982). The total soluble salts (EC) were determined using electrical conductivity meter at $25^{\circ} \mathrm{C}$ in soil paste extract (Jackson, 1973).

Particle size distribution was determined by the pipit method descriped by Gee and
Bauder (1986) using sodium hexametaphosphate as a dispersing agent. Soil bulk density and Hydraulic conductivity were determined according to the method of Richard (1954). Total soil porosity was calculated as percentage from the obtained values of soil real and bulk densities (Richards, 1954). Wilting point was determined according to Stakman and Vanedrhast (1962), field capacity being determined as described by Richards (1954). Stability of water stable aggregates was determined using the wet sieving technique described by Yoder (1936) and modified by Ibrahim (1964). At harvest stage after 150 day from planting, the yield of biological, grain and weight of 100 grains were weight for each plot and estimated as ton fed $^{-1}$. Obtained results were subjected to statistical analysis according to Snedecor and Cochran (1980) and the treatments were compared by using the least significant difference (L. S. D at 0.05 level of probability).

Table (1): Physical and chemical properties of the studied soil.

\begin{tabular}{|c|c|c|c|c|c|c|c|c|c|}
\hline \multicolumn{4}{|c|}{ Particale size distribution } & \multirow[t]{2}{*}{ Soil texture } & \multirow{2}{*}{$\begin{array}{l}\text { OM } \\
\%\end{array}$} & \multirow{2}{*}{$\begin{array}{l}\mathrm{CaCO}_{3} \\
\%\end{array}$} & \multirow{2}{*}{\begin{tabular}{|l|}
$\mathrm{EC}$ \\
$\mathrm{dS} \mathrm{m}^{-1}$
\end{tabular}} & \multirow{2}{*}{$\begin{array}{l}\mathrm{pH} \\
(1: 2.5) \\
\text { water sus. }\end{array}$} & \multirow{2}{*}{$\begin{array}{l}\mathrm{BD} \\
\mathrm{g} \mathrm{cm}^{-1}\end{array}$} \\
\hline $\begin{array}{c}\text { Coars } \\
\text { Sand } \\
\%\end{array}$ & $\begin{array}{c}\text { Fine } \\
\text { Sand } \\
\%\end{array}$ & $\begin{array}{c}\text { Silt } \\
\%\end{array}$ & $\begin{array}{c}\text { Clay } \\
\%\end{array}$ & & & & & & \\
\hline 8.70 & 53.9 & 22.4 & 15.0 & Sandy loam & 0.92 & 17.36 & 2.35 & 8.35 & 1.24 \\
\hline \multicolumn{5}{|c|}{ Soluble cations (meq L-1) } & \multicolumn{5}{|c|}{ Soluble anions (meq $\mathrm{L}^{-1}$ ) } \\
\hline $\mathrm{K}^{+}$ & \multicolumn{2}{|c|}{$\mathrm{Na}^{+}$} & $\mathrm{Mg}^{++}$ & $\mathrm{Ca}^{++}$ & \multicolumn{2}{|c|}{$\mathrm{SO}_{4}^{--}$} & $\mathrm{CL}^{-}$ & $\mathrm{HCO}_{3}^{-}$ & $\mathrm{CO}_{3}^{--}$ \\
\hline 0.5 & \multicolumn{2}{|c|}{9.0} & 7.5 & 6.5 & \multicolumn{2}{|c|}{8.5} & 9.5 & 3.5 & 2.0 \\
\hline
\end{tabular}

Table (2 -a): Some characteristic of compost used in the experiment

\begin{tabular}{|c|c|c|c|c|c|c|c|}
\hline $\begin{array}{c}\mathrm{EC} \mathrm{dSm}^{-1} \\
1: 10 \\
\text { Water extr }\end{array}$ & $\begin{array}{c}\mathrm{pH} \\
1: 10 \\
\text { Water susr }\end{array}$ & $\begin{array}{c}\mathrm{OM} \\
\%\end{array}$ & $\begin{array}{c}\mathrm{OC} \\
\%\end{array}$ & $\begin{array}{c}\mathrm{ClN} \\
\text { ratio }\end{array}$ & $\begin{array}{c}\text { Total N } \\
\%\end{array}$ & $\begin{array}{c}\text { Total P } \\
\%\end{array}$ & $\begin{array}{c}\text { Total K } \\
\%\end{array}$ \\
\hline 3.15 & 7.13 & 27.82 & 31.78 & 23.37 & 1.36 & 0.69 & 0.58 \\
\hline
\end{tabular}

Table (2- b): Some characteristic of potassioum humate used in the experiment

\begin{tabular}{|c|c|c|c|c|c|c|}
\hline Humic acid \% & $\begin{array}{c}\text { Fulvic } \\
\text { acid \% }\end{array}$ & $\mathrm{EC} \quad \mathrm{dSm}^{-1}$ & $\mathrm{pH}$ & $\begin{array}{c}\text { Total } \mathrm{N} \\
\%\end{array}$ & $\begin{array}{c}\text { Total } \mathrm{P} \\
\%\end{array}$ & $\begin{array}{c}\text { Total } \mathrm{K} \\
\%\end{array}$ \\
\hline 26.6 & 16.1 & 80.8 & 7.27 & 3.5 & 1.1 & 4.2 \\
\hline
\end{tabular}




\section{RESULTS AND DISCUSSION Soil chemical properties:-}

The effect of different treatments on some soil chemical properties data presented in Table (3) appeared that, application of conditioners decreased the soil $\mathrm{EC}, \mathrm{pH}$ and $\mathrm{CaCO}_{3}$ values. The same data indicated that, the lowest values of soil $\mathrm{EC}, \mathrm{pH}$ and $\mathrm{CaCO}_{3}$ induced in the soil treated by town refuse compost in row cultivation method. The obtained results manifested that, the different conditioners play an important role in reduction of soil EC and $\mathrm{pH}$ of the studied soil compared to control. Data also showed a slightly effect of different conditioners on soil $\mathrm{CaCO}_{3}$. This may be attributed to decomposition of organic materials and the production of organic acids and lor increased partial pressure of $\mathrm{CO}_{2}$ in the soil at mesosphere due to increased microbiological activity leading to decrease the soil EC, $\mathrm{pH}$ and $\mathrm{CaCO}_{3}$. These results are similar to that found by EL-Maaz, et al. (2010). On the other hand the percentage of OM was positively influenced with both conditioners and cultivation methods. This may be due to higher OM content of those conditioners consequently augmented the OM content of soil received these material. These results are in agreement in the findings of Aiad, Nahed (2010) who found that, the application of compost significantly increased both OM and CEC compared to control $(100 \%$ NPK). Generally, the different chemical calcareous soil properties was more affected by the row cultivation method, town refuse compost and potassium humate, than bio fertilizer addition compared to the control.

Table (3): Effect of compost, potassium humate and biofertilizer on some chemical properties of the tested soil.

\begin{tabular}{|c|c|c|c|c|c|}
\hline \multicolumn{2}{|c|}{ Treatments } & $\mathrm{pH}$ & $\mathrm{EC}$ & OM & $\mathrm{CaCO}_{3}$ \\
\hline $\begin{array}{l}\text { cultivation } \\
\text { methods } \\
\text { (A) }\end{array}$ & $\begin{array}{l}\text { Conditioers } \\
\text { (B) }\end{array}$ & $1: 2.5$ & $d S m^{-1}$ & $\%$ & $\%$ \\
\hline \multirow[b]{4}{*}{ Row } & control & 8.35 & 2.35 & 0.94 & 17.29 \\
\hline & compost & 8.12 & 1.47 & 1.24 & 15.11 \\
\hline & K-Humate & 8.17 & 1.49 & 1.18 & 15.25 \\
\hline & Biofertilize & 8.29 & 1.98 & 1.05 & 16.39 \\
\hline \multicolumn{2}{|c|}{ Mean $(A)$} & -- & 1.80 & 1.10 & 16.01 \\
\hline \multirow{4}{*}{ Strew } & control & 8.33 & 2.25 & 0.93 & 17.36 \\
\hline & compost & 8.15 & 1.11 & 1.19 & 15.95 \\
\hline & K-Humate & 8.20 & 1.16 & 1.15 & 16.23 \\
\hline & Biofertilize & 8,24 & 1.76 & 1.02 & 16.93 \\
\hline \multicolumn{2}{|c|}{ Mean $(A)$} & -- & 1.57 & 1.13 & 16.62 \\
\hline \multirow{4}{*}{$\begin{array}{l}\text { Means } \\
\text { (B) }\end{array}$} & control & -- & 2.30 & 0.94 & 17.32 \\
\hline & compost & -- & 1.29 & 1.21 & 15.53 \\
\hline & K-Humate & -- & 1.32 & 1.16 & 15.74 \\
\hline & biofetilizer & -- & 1.87 & 1.03 & 16.66 \\
\hline \multirow{3}{*}{$\begin{array}{c}\text { LSD } \\
0.05 \%\end{array}$} & A & -- & ns & $\mathrm{ns}$ & ns \\
\hline & $B$ & -- & 0.42 ** & $0.18^{\star \star}$ & $0.91^{\star \star}$ \\
\hline & $A \times B$ & -- & ns & $\mathrm{ns}$ & ns \\
\hline
\end{tabular}


Physical properties:

Bulk density, total porosity, hydraulic conductivity and Soil moisture parameters

The two properties of bulk density and total porosity are closely related and linearly inversely correlated and decreased bulk density is a direct function of increased total porosity (Black et al., 1965). Data in Table (4) revealed that, the values of soil bulk density were decreased with different treatments; value of row methods was lower than those of strew methods or control treatment. These decreases may be resulted from soil aeration due to increases in soil porosity with the structural stability. On the other hand, data showed that, values of total porosity and hydraulic conductivity tended to increase with application of different conditioners compared to control. Application of compost treatment gave the lowest decrease of soil bulk density and highest increase of hydraulic conductivity in row cultivation method. Consequently, porosity as an index of the relative volume of soil pores should be improved due to the beneficial effect of organic conditioners in improving soil aggregates. These results are in consonance with the findings of Noufal et al. ( 2005) and Evanylo et al. (2008) who reported an increase in total porosity as well as decrease in bulk density. The obtained data also showed that, values of soil field capacity, wilting point and the calculated available water are considered to be the three main soil moisture constants were obviously responded to applied treatments. Data appeared that compost and potassium humate in row cultivation method was favorable for FC\%, WP\% and AW\% compared to the control.

Table (4): Effect of compost, potassium humate and biofertilizer on some physical properties of the tested soil.

\begin{tabular}{|c|c|c|c|c|c|c|c|}
\hline \multicolumn{2}{|c|}{ Treatments } & \multirow{2}{*}{$\begin{array}{c}\text { BD } \\
\mathrm{g} \mathrm{cm}^{-1}\end{array}$} & \multirow{2}{*}{$\begin{array}{l}\text { TP } \\
\%\end{array}$} & \multirow{2}{*}{$\begin{array}{c}\mathrm{HC} \\
\mathrm{Cm}^{3} \mathrm{~h}^{-1}\end{array}$} & \multicolumn{3}{|c|}{ Soil moisture parameters } \\
\hline $\begin{array}{l}\text { cultivation } \\
\text { methods } \\
\text { (A) }\end{array}$ & $\begin{array}{c}\text { Condioners } \\
\text { (B) }\end{array}$ & & & & FC \% & WP \% & AW \% \\
\hline \multirow{4}{*}{ Row } & control & 1.23 & 53.58 & 2.75 & 18.87 & 11.11 & 7.76 \\
\hline & compost & 1.09 & 58.86 & 7.17 & 20.62 & 11.99 & 8.62 \\
\hline & K-Humate & 1.11 & 58.11 & 5.42 & 20.19 & 12.66 & 8.49 \\
\hline & biofertilize & 1.19 & 55.09 & 3.98 & 19.71 & 11.53 & 8.18 \\
\hline \multicolumn{2}{|c|}{ Mean (A) } & 1.16 & 56.41 & 4.83 & 19.85 & 11.82 & 8.26 \\
\hline \multirow{4}{*}{ Strew } & control & 1.23 & 53.58 & 2.58 & 17.35 & 10.34 & 7.02 \\
\hline & compost & 1.15 & 56.60 & 5.74 & 18.44 & 10.89 & 7.54 \\
\hline & K-Humate & 1.17 & 56.98 & 4.48 & 18.37 & 10.85 & 7.52 \\
\hline & biofertilize & 1.21 & 54.71 & 3.78 & 18.05 & 10.69 & 7.36 \\
\hline \multicolumn{2}{|c|}{ Mean $(\mathrm{A})$} & 1.19 & 55.09 & 4.14 & 18.05 & 10.69 & 7.36 \\
\hline \multirow{4}{*}{$\begin{array}{c}\text { Means } \\
\text { (B) }\end{array}$} & control & 1.23 & 53.58 & 2.66 & 18.11 & 10.72 & 7.39 \\
\hline & compost & 1.12 & 57.73 & 6.45 & 19.53 & 11.44 & 8.08 \\
\hline & K-Humate & 1.14 & 57.54 & 4.95 & 19.28 & 11.75 & 8.00 \\
\hline & biofertilize & 1.20 & 54.90 & 3.88 & 18.88 & 11.11 & 7.77 \\
\hline \multirow{3}{*}{$\begin{array}{l}\text { LSD } \\
0.05 \%\end{array}$} & A & ns & ns & ns & $\star \star 1.54$ & $\star \star 0.74$ & $\star \star 0.58$ \\
\hline & $B$ & ns & ns & $\star \star 1.69$ & ns & ns & ns \\
\hline & $A \times B$ & ns & ns & ns & ns & ns & ns \\
\hline
\end{tabular}

Note : soil real density about $2.65 \mathrm{gm} \mathrm{cm}^{-1}$ 


\section{Soil aggregation stability:}

Distribution of stable aggregates showed marked variation associated with different treatments. The aggregate categories studied in this experiment are of the following diameters $(\mathrm{mm}): 10-2,2-1,1-0.5$, $0.5-0.25,0.25-0.125,0.125-0.063$ and $<0.063$. For reasons of data presentation they are designated as follows, respectively: very large, large, medium, sub- medium, small, very small and extremely small. Dry aggregation covered the 7 categories, but wet aggregation (because of its nature) covered the first 6 categories. Data in Table (5) showed that, values of dry sieving aggregates \% of the studied soil samples were affected by compost, K- Humat and biofertilizer additions. Dry stable aggregates having diameters of $10-2 \mathrm{~mm}$ were found to be the largest size present in the different treatments under study, followed by diameters 1- 0.5; percentage of other sizes especially the aggregates with diameters less than $0,063 \mathrm{~mm}$ which as usually the lowest values (Cox et al., 2001). Robert
(2011) reported that, the Humic substances are key components of soil crumbs (aggregates). Complex carbohydrates synthesized by bacteria and humic substances function together with clay and silt to form soil aggregates. As the humic substances become intimately associated with the mineral fraction of the soil, colloidal complexes of humic - clay and humus silt aggregates are formed. Similar results were in agreement with that obtained by Darwich et al. (2012). Table (6) showed that, comparison between the different treatments concerning total of stable aggregate (TSA) show little differences between them, row cultivation gave lower values than strew cultivation, compost tended to aggregation and aggregate stability in soil particularly with row cultivation. The same results are in agreement in the findings of El- Maghraby et al, (2011). The positive and favorable effect of compost on soil physical properties is a manifestation of the influence of organic matter in creating soil structure favorable for plant growth.

Table (5). Dry stable aggregates distribution (\%) of the studied soil as affected by compost, K-Humate and biofertilizer.

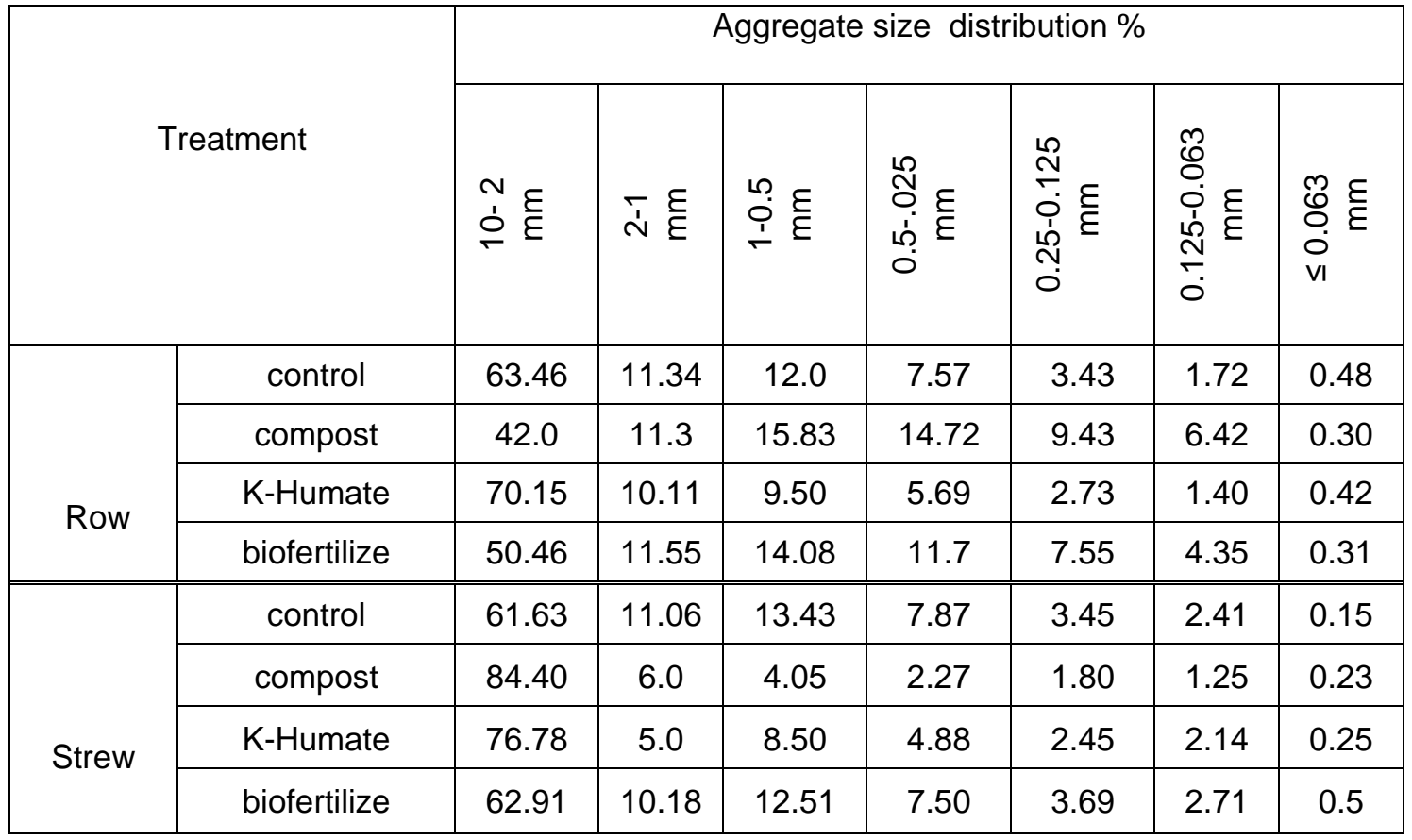


Table (6): Water stable aggregates distribution (\%) and total stable aggregates as affected by compost, K-Humate and biofertilizer in studied soil.

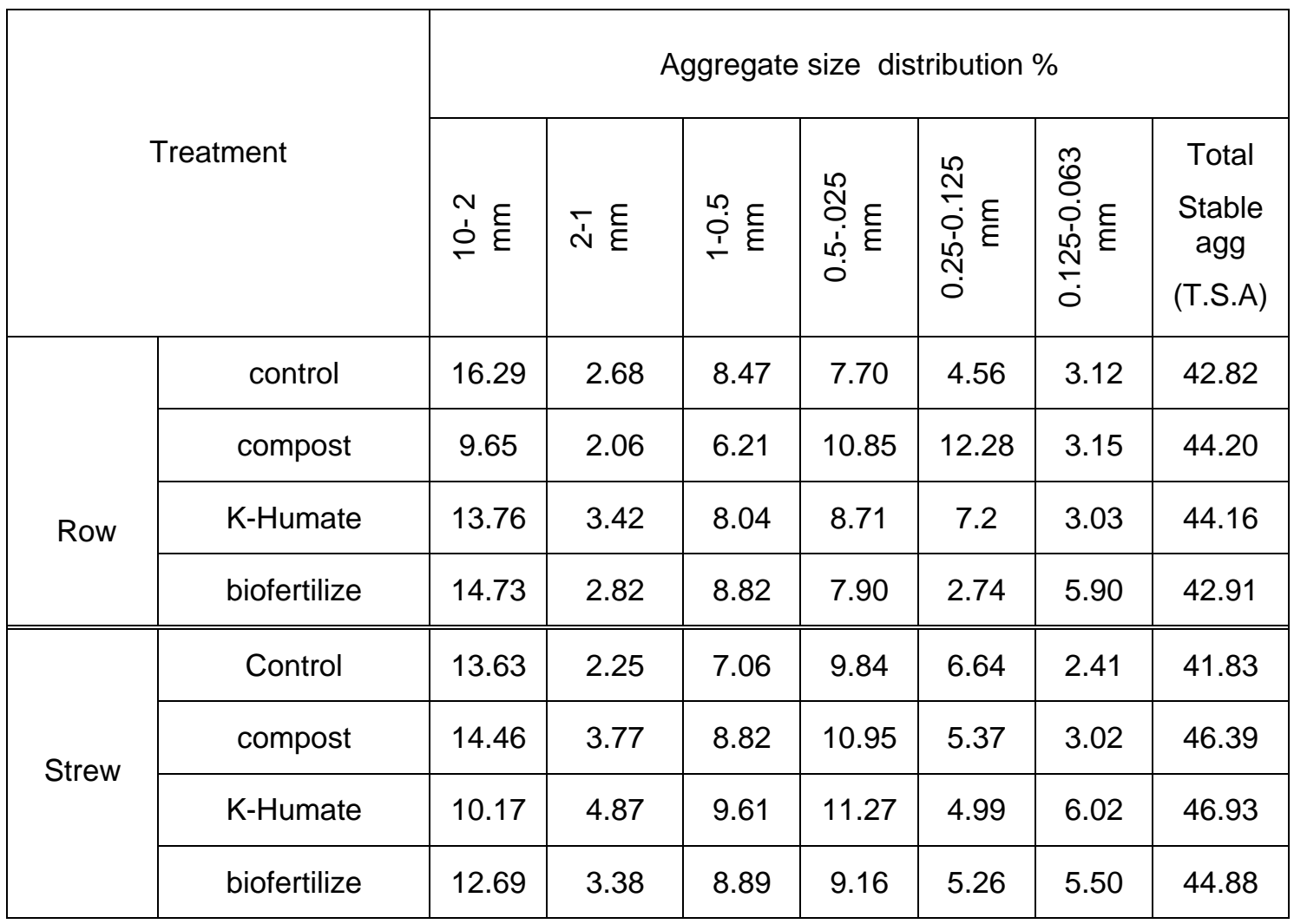

\section{Biological yield, grain yield and weight of $\mathbf{1 0 0}$ grain:}

Data in Table (7) showed that, application of compost, K-Humate and biofertilizer (Rhizobium) resulted in an increases in biological yield, grain yield and 100 grains weight. The magnitude of increase depended on the type of OM applied. The highest biological, grain yield and 100 grains weight values were obtained under compost applied with row cultivation method followed by potassium humate apllication. Saruhan et al, (2011) revealed that humic compounds added to soil increased the soil fertility through increasing the soil microbial population including beneficial microorganisms. They explained that humic substances are major components of organic matter, often consisting 60 to $70 \%$ of the total organic matter, thus they may enhance the plant nutrients uptake through stimulation of microbiological activity. Ulkan (2008) postulated that addition of humic acid to soil in wheat cultivation stimulated the soil microbiological activity that led to increase the soil fertility. These results are in agreement with the results of El-Maaz et al. (2010) and Eletr et al. (2013). Also data revealed that, superiority of organic treatments over biofertilizer in all yield parameters and row cultivation method. High signefical increased for biological yield as affected by conditioners compared to control. Row cultivation method gave high signefical increased for grain yield over the strew method. The row method of cultivation is thus an efficient method of many crops which are most suited to row method (Abd El- Salum et al., 2006). 
Table (7): Effect of compost, potassium humate and biofertilizer on some growth parameters of broad bean plant.

\begin{tabular}{|c|c|c|c|c|}
\hline \multicolumn{2}{|c|}{ Treatments } & \multirow{2}{*}{$\begin{array}{l}\text { Biological } \\
\text { Yield }\end{array}$} & \multirow{2}{*}{$\begin{array}{l}\text { Grain yield } \\
\text { Ton fed }^{-1}\end{array}$} & \multirow{2}{*}{$\begin{array}{c}\text { Weight of } \\
100 \text { grain } \\
\text { gm }\end{array}$} \\
\hline $\begin{array}{l}\text { cultivation } \\
\text { methods } \\
\text { (A) }\end{array}$ & $\begin{array}{l}\text { Condioners } \\
\text { (B) }\end{array}$ & & & \\
\hline \multirow[t]{4}{*}{ Row } & control & 3.077 & 2.077 & 75,16 \\
\hline & compost & 4.255 & 2.510 & 80.32 \\
\hline & K-Humate & 3.854 & 2.377 & 78.79 \\
\hline & biofetilizer & 3.522 & 2.255 & 77.51 \\
\hline \multicolumn{2}{|c|}{ Mean } & 3.677 & 2.30 & 77.94 \\
\hline \multirow[t]{4}{*}{ Strew } & control & 3.066 & 1.944 & 74.25 \\
\hline & compost & 3.849 & 2.410 & 78.22 \\
\hline & K-Humate & 3.833 & 2.299 & 76.38 \\
\hline & biofertilizer & 3.216 & 2.199 & 75.25 \\
\hline \multicolumn{2}{|c|}{ Mean } & 3.491 & 2.213 & 76.02 \\
\hline \multirow{4}{*}{ Means } & control & 3.071 & 2.01 & 74.70 \\
\hline & compost & 4.052 & 2.45 & 79.27 \\
\hline & K-Humate & 3.838 & 2.338 & 77.58 \\
\hline & biofetilizer & 3.369 & 2.227 & 76.38 \\
\hline \multirow{3}{*}{$\begin{array}{l}\text { LSD } \\
0.05 \%\end{array}$} & A & ns & $\star \star 1.99$ & ns \\
\hline & B & $\star * 0.72$ & ns & ns \\
\hline & $A \times B$ & ns & ns & ns \\
\hline
\end{tabular}

\section{Conclusion:-}

The application of compost (town refuse) 10 ton fed $^{-1}$ and potassium humate $15 \mathrm{~L}$ fed ${ }^{1}$ and biofertilizer (Rhizobium) showed a beneficial effect on the chemical and physical properties of the tested soil. Generally, the different chemical calcareous soil properties were more affected by the row cultivation method, town refuse compost and potassium humate, than bio fertilizer addition. Superiority of compost, potassium humate and row cultivation method to improve soil bulk density, total porosity, hydraulic conductivity and soil moisture constants over bioferilizer (Rhizobium) was observed. Row cultivation gave lower values than strew cultivation, compost and potassium humate tended to aggregation and aggregate stability. The highest biological, grain yield and 100 grains weight values were occurred by compost applied with row cultivation method followed by potassium humate application.

\section{REFERENCES}

Abd El-Moez, M.R., O. Shaleby, I.A. Abdel Latif and K.S. Abd El Fattah (2002). Impact of some organic residues on some roperties of calcareous soil and tomato germination. Egypt J, Soil Sci. 42 (2): 255-265.

Abdel- Salam, A.A., M. A. M. Ibrahim, H.H. Abass and M. M. Kassab (2006). Interaction relationships of irrigation level and furrow spacing on crop water 
parameters of sunflower, Annalsof Agric. Sci. Moshtohor 44(2): 769-774.

Aiad, Nahed, A. M. E. (2010). Application of organic wastes for sustainable agriculture. Ph.D. Thesis, Fac . Agric, Minufiya Univ, Egypt.

Bhat, A., M. Gupta, M. A. Ganai, R. A Ahanger and H. A. Bhat (2013). Yield, soil health and nutrient utilization of field pea ( pisum sativum I.) as affected by phosphorus and bio -fertilizers under subtropical conditions of Jammu. International Journal of Modern Plant \& Animal Sciences 1:1-8.

Black, C. A., D.D. Evans, L.E. Ensminger, J. L. White and F. E. Clark (1965). Methods of soil analysis Am. Soc of Agronomy . Agronomy Series No.9, Madison. Wisconsin, USA.

Choudhury, A. T. M. A., M. L. Kecsk and I. R. Kennedy (2014). Utilization of BNF technology supplementing urea $\mathrm{N}$ for sustainable rice production. Journal of Plant Nutrition 37:1627-1647.

Cox, D., D. Bezdicek and M. Fauci (2001). Effect of compost, coal ash and straw amendments on restoring the quality of eroded Palouse soil Biol. Ferti Soils 33: 365-372.

Darwich, M. A., Ensherah, I.M. EL-Maaz and Hoda M. R. M. Ahmed (2012). Effect of mineral nitrogen, sulpher, organic and bio- fertilizations on some physical and chemical properties and maize productivity in saline soil of Sahl El-Tina. Jour of Appl Sci Res, 8: 5818-5828.

Eletr, Wafaa, M.T., F. M. Ghazal, A. A. Mahmoud and H. Yossef (2013). Responses of wheat- rice cropping system to cyanobacteria inoculation and different soil conditioners sources under saline soil. Nature and Science 11:118129.

El-Maaz, E.I.M., H.M.R.M. Ahmed and Kh. A. Shaban (2014). Soil chemical properties and wheat productivity as affected by organic, bio fertilization and cultivation methods in saline soil.
Minufiya, J. Agric Res., 39 (6): 19551968.

El-Maaz, Enshrah, I. M., Hoda M. R. M. Ahmed, Nadia A. Mohamed and H. M. Khalil (2010). Effect of farming methods and organic manures on calcareous soil properties and crop productivity. Minufiya. J. Agr. Res. 35 :2281- 2295.

El-Maghraby, T. A., M. A. A. Abdel-Salam and M. Abdel-Warth (2011). Effect of compost on maize (Zea mays) yield and some clay soil physical properties under deficit irrigation. J. Soil Sci. and Agric Eng., Mansoura Univ.2:611-622.

Evanylo, G., C. Sherony, J. Sprage, D. Starner, M. Brosius and K. Hearing (2008). Soil and water Environmental effects of fertilizer, manure and compostbased fertility practices in organic vegetable cropping systems Agric. Ecosystems and Environment 127:50-58.

Gee, G. W. and J. W. Bauder (1986). Partial Size Analysis in Methods of Soil Analysis. Klute, Ed, Part 1, Agron. Madison, Wisconsin, U. S. A.

Ibrahim, S. A. (1964). Studies on the size distribution of water table aggregates in the soil of the Nile Delta. M. Sc. Thesis, Fac. of Agric., Ain- shams Univ., Egypt.

Jackson, M. L. (1973). "Soil Chemical Analysis Prentice Hall of Indian Private Limited". New Delhi. India.

Kassem, M.M. and B.A. Hassouna (2004). Efficiency of seed inoculation with $\mathrm{N}$ fixing bacteria in decreasing the mineral requirements for early and late sown cotton planting. J. Agric. Sci. Mansoura Univ., 29(2): 517 - 526.

Marschner, H. (1995). Mineral Nutrition of Higher Plants. $2^{\text {nd }}$ Ed. Academic Press. Harcourt Brace and Company Publishers, New York

Metin, T.A., G.B. Medine, C.C. Ramazan, O.F. Taskin and D. Sahin (2010). The effect of PGPR strain on wheat yield and quality parameters. Proceeding of Worled CLongress of Soil Science, Soil Solutions for a Changing World., Brisbane, Australia. 
Naher, U.A., Q.A. Panhwar, R. Othman, M.R. Ismail and Z. Berahim (2016). Fertilizer as a Supplement of Chemical Fertilizer for Yield Maximization of Rice. Journal of Agriculture Food and Development., 2:16-22.

Noufal, E. H. A., F. M. Habib, M.G. Khalil and M.S. S. Abd El- Ha. (2005). Effect of natural organic conditioners addition on some properties of some nutrients and their uptake by barley plant grown thereon. 1-physical and chemical properties. Egypt. J. Agric. Res 2(1):35 58.

Page, A. L., R. H. Miller and D. R. Keeny (1982). Methods of soil analysis. Part 2chemical and microbiological properties Second Edition Amer. Soc. of Agron. Madison, Wisconsin, USA. 5371.

Richards, A. L. (1954). "Diagnosis and improvement of saline alkali soils". U.S. Dept. Agric. Hand Book, No 60, USA.

Robert, E. P. (2011). Organic Matter, Humus, Humate, Humic acid, Fulvic acid and Humin: Their importance in soil fertility and plant health. Taxas. A \& M. University.

Saruhan, V., A. Kasvuran and S. Babat (2011). The effect of different HA fertilization on yield and yield component performances of common millet (Panicum miliaceum L.). Scient. Res. Ess.6: 663-669.

Singh, S.P. (2014). Effect of bio- fertilizer Azospirillum on growth and yield parameters of coriander ) Coriandrum sativum L.) cv. Pant Haritima. International J. Seed Spices 4(2):73 -76.

Snedecor, G. W. and W. G. Cochran (1980). Statistical Methods. $7^{\text {th }}$ Edition. Iowa State Univ. Press. Amer., IA., USA.

Stakman, W. P. and G. G. Vanderhast (1962). The use of the pressure membrane apparatus to determine soil moisture constants at P. F 3.0 to 4.2 inclusive. Institute for Land and Water Management Res. Note No 139.

Tahoun, S.A., E.A. Abdel-Bary and NA. Atia (2000). A greenhouse trial in view of organic farming in Egypt. Egyptian Journal of Soil Science 40: 469-479.

Ulkan, H. (2008). Effect of soil applied humic acid at different sowing time on some yield components in wheat (Triticum spp.) Hybrids. Inter. J. Bot., 164 - 175.

Yoder, R. E. (1936). A direct method of aggregate analysis of soils a study of the physical nature of erosion losses. J. Amer. Soc. Agron. 28: 337- 351.

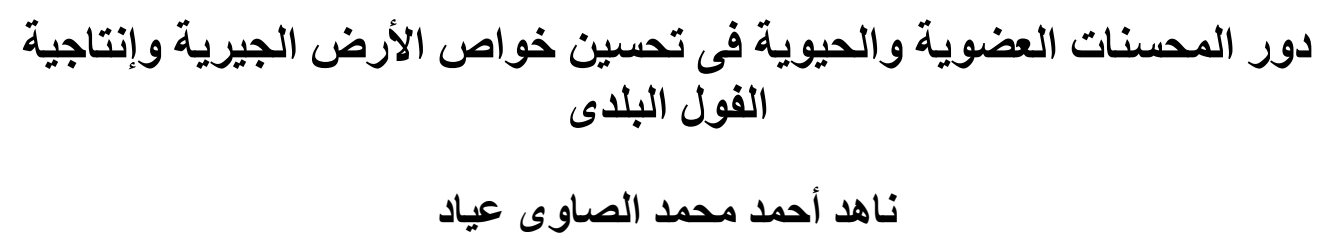


معهة بحوث الأر اضى و المياة والبيئة ــ مركز البحوث الزراعية ــ الجيزة

الملخص العربى

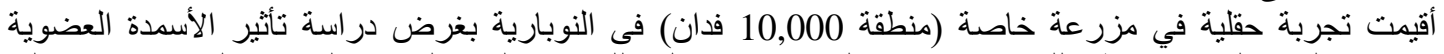

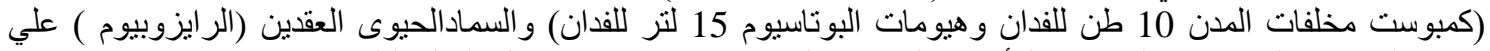

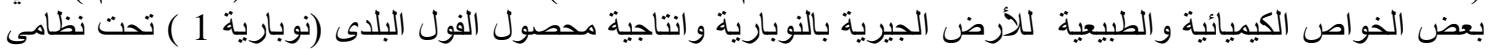
زر اعة (خطوط - نقر) خلال موسمين شتوى متتالين( 2015 -2016 ) و و2016- 2017) وذلك فى تصميم قطع منشقة مرة

و واحدة

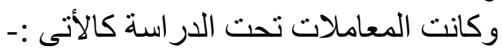

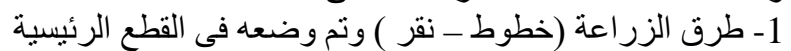

2- المحسنات العضوية (الكمبوست 10 طن للفدان و وهيومات البوتئتاسيوم 15 لتر للفدان) و السماد الحيوى العقدين (الرايزوبيوم)

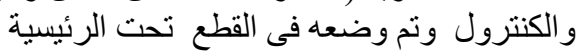

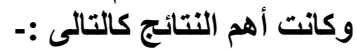

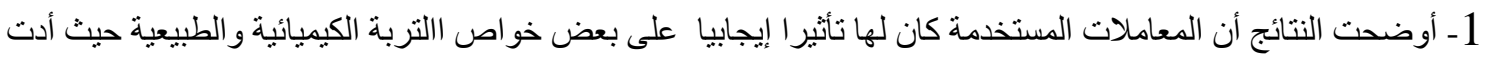

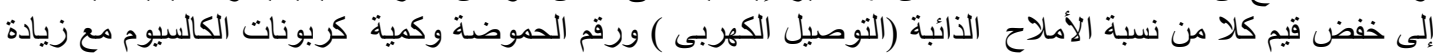

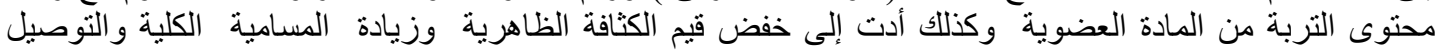

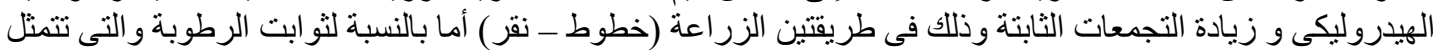

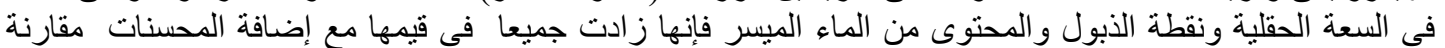
بالكنترول

2- أظهرت النتائج تفوق التاثير الإيجابى لطريقة الزراعة على خطوط على الخو اص الكيميائية والطبيعية على طريقة

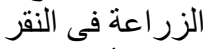

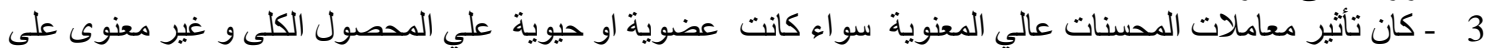

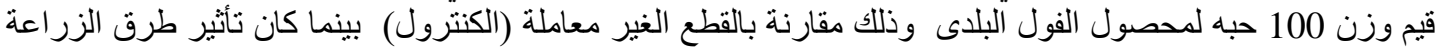

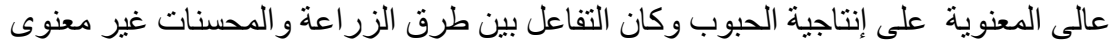

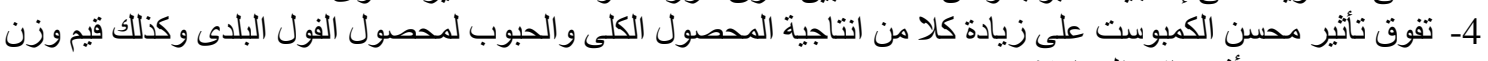

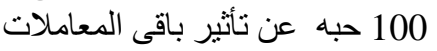

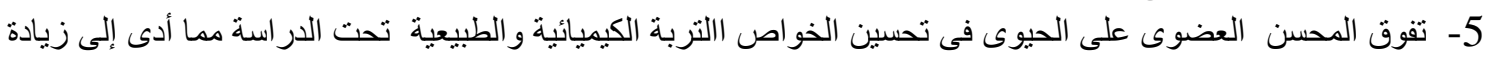
كلا من انتاجية المحصول الكلى و الحبوب لمحصول الفول البلدى وكذللك قيم وزن 100 حبه الفيه 